\title{
Substitusi White Wine Dalam Pengolahan Citrus Sauce
}

\author{
Swastono Putro Pirastyo ${ }^{1}$, Roby Sahid ${ }^{2}$ \\ Akademi Pariwisata Nasional Indonesia Bandung, Swastono.putro@gmail.com
}

\begin{abstract}
ABSTRAK
Saus adalah salah satu bagian terpenting dalam penyajian makanan. Sebagai dressing, saus memiliki peran yang besar untuk dapat membuat makanan menjadi lebih menarik. Dalam hal rasa, saus juga memiliki peran besar untuk meningkatkan citarasa dan tekstur dari hidangan. Seni dalam mengolah saus berkembang sangat luas, melingkupi teknik pengolahan, proses pemasakan dan juga bahan baku. Dari segi bahan baku, muncul sedikit permasalahan, saat berbicara mengenai aspek halal, sebab sebagian besar saus masakan Eropa mengandung bahan baku tidak halal. Lard, pork, dan berbagai jenis minuman beralkohol dapat dikategorikan tidak halal. Penelitian ini dilakukan untuk menemukan bahan alternatif pengganti white wine dalam citrus sauce. Bahan baku yang terpilih untuk diuji adalah Sprite, Cuka Apel, dan Château de Reignac. Penelitian ini menggunakan uji organoleptik untuk menguji produk hasil percobaan. Sebagai hasilnya, kombinasi terbaik yang paling mendekati saus asli adalah kombinasi dari Sprite dan Cuka Appel. Dengan menggunakan kombinasi tersebut, juru masak dapat menciptakan citrus saus yang halal bagi konsumen.
\end{abstract}

Kata Kunci : Saus, White Wine, Tidak Halal, Bahan Baku Alternatif.

\begin{abstract}
The sauce is one of the most important part in any meal serving. As a dressing, sauces have a big part in delighting the menu. In the matter of taste, the sauce also has a great part to enrich the taste and texture of the meal. The art of sauce creation became so wide, including the technique, the cooking process, and also the ingredients. In the ingredient aspect, a little problem is shown, when we talk about Halal, because most of the European sauce have non-halal ingredient inside. Lard, pork, and any kind of alcoholic drink can categories as non-halal material. This study is conducted to find alternative ingredients to replace the use of white wine in Citrus Sauce. There are plenty of choices of alternative ingredients, but this study focused on 3 main ingredients, Sprite, Apple Vinegar, and Chateau de Reignac. This study uses an Organoleptic test to test the final experiment product. As a result, the combination of Sprite and Apple Vinegar was proven as the most identical taste, aroma, color, and texture to the original White Wine Citrus Sauce. By using this combination, a cook can recreate halal and worry-free citrus sauce for the customer.
\end{abstract}

Keyword: Sauce, White Wine, Non-halal, Alternative Ingredient.

Diterima: 9 Agustus 2020, Direvisi: 26 Agustus 2020, Diterbitkan: 27 Agustus 2020

\section{PENDAHULUAN}

Sauce merupakan bagian penting dari penyajian makanan. Menurut (Cahyana \& Devi, 2015) saus atau dressing cairan yang dikentalkan (semi liquid) dengan rasa kecut dan tajam. Rasa saus sebaiknya lebih menonjol dari bahan utama. Tidak hanya sebagai pemanis, namun kehadiran saus dalam penyajian makanan juga turut memberi nilai nutrisi dan dapat berfungsi sebagai penyeimbang rasa. Lebih dari itu, bagian yang paling dapat dikenang dari hidangan yang sempurna adalah saus yang memperkaya hidangan daging atau ikan (Gisslen, 2011).
Berbagai bahan baku dapat diolah dan dikembangkan menjadi saus. Namun, dapat ditemui bahwa dalam pengolahannya, melibatkan penggunaan bahan baku yang tidak masuk kedalam kategori halal, salah satunya adalah bahan yang mengandung alcohol. Minuman yang halal dari segi zat, adalah minuman yang tidak mengandung unsur haram dan memabukkan (Wahyudin, Fathurrahman, \& Fuziani, 2008). Sehingga dapat diasumsikan bahwa bahan makanan (maupun minuman) yang mengandung unsur alcohol dan berpotensi memabukkan adalah haram hukumnya. 
Bahan non halal yang sering digunakan dalam penggolahan makanan dan sering juga digunakan dalam pembuatan sauce adalah minuman beralkohol, rhum dan angciu.

Salah satu saus turunan (small sauce) dari Saus Hollandaise yang menggunakan wine sebagai bahan bakunya adalah Beurre Blanc. Beurre Blanc sendiri merupakan saus berbahan dasar butter yang diemulsi yang dibuat tanpa menggunakan kuning telur (Labensky, Hause, \& Martel, 2015). Salah satu variasi pengembangan saus Beurre Blanc adalah Saus Lemon-Dill, yang menjadi dasar pengembangan Citrus Sauce.

Pada penelitian ini penulis tertarik untuk membuat citrus sauce dengan menggunakan bahan alternatif lain seperti minuman berkarbonasi seperti Sprite, cuka apel atau chateau de reignac. Untuk mengetahui dampak atau penggaruh dari penggunaan bahan alternatif dalam pembuatan citrus sauce.

Pada umumnya pembuatan citrus sauce menggunakan bahan white wine. Penggunaan bahan alternatif dalam pembuatan citrus sauce ini bertujuan untuk mencari alternatif bahan yang tidak menggandung alkohol dan agar bisa dikonsumsi oleh semua orang khususnya bagi umat muslim. Oleh karena itu penulis tertarik untuk mengangkat ke dalam penelitian dengan judul Inovasi Bahan Alternatif Pengganti White Wine dalam Pembuatan Citrus Sauce. Tujuan dari penelitian ini adalah untuk mengetahui, bahan baku apa yang dapat digunakan untuk mengganti white wine dalam membuat citrus sauce menjadi halal, serta untuk mengetahui tekstur, warna, aroma, dan rasa pada penggunaan bahan alternatif yang sudah dilakukan pada citrus sauce.

\section{LITERATUR REVIEW}

\section{Pengertian Sauce}

Saus didefenisikan sebagai cairan yang kaya rasa, dikentalkan, digunakan sebagai season, penambah rasa dan menambah nilai suatu makanan (Gisslen, 2011). (Minantyo, 2011) menambahkan bahwa saus dibuat dengan atau tanpa proses pemasakan yang disertakan dalam suatu hidangan, baik dalam keadaan panas maupun dingin.

Lebih lanjut Gisslen (2011) juga menyampaikan bahwa saus dapat memberi nilai tambah kepada makanan berupa:

1. Kelembaban

2. Rasa

3. Kekayaan

4. Penampilan (warna dan kilau)

\section{Minat dan daya tarik selera}

Sehingga berdasarkan pengertian diatas, dapat dipahami Bersama bahwa saus merupakan cairan yang pada umumnya bersifat kental, yang berfungsi untuk dapat menambah citarasa kedalam suatu hidangan.

Pada dasarnya, saus dibangun dari 3 struktur utama sebagai berikut, liquid sebagai badan utama, tickening agent sebagai pemberi tekstur dan bahan perasa serta bumbu tambahan (Gisslen, 2011). Liquid yang digunakan dapat berupa cairan hasil perebusan (kaldu) daging, ayam, ikan maupun sayuran. Agen pengental yang digunakan untuk membangun tekstur saus juga beragam, tergantung daripada jenis dan peruntukan saus tersebut, seperti roux, beurre manie, whitewash, cornstarch, gelatine, dan lain sebagainya.

Kriteria suhu yang baik untuk makanan atau sauce yaitu dengan suhu dingin sekali $(5 \mathrm{oC}$ atau lebih dingin) atau panas $(60 \mathrm{oC}-90 \mathrm{oC})$.

Saus terdiri dari 2 kategori besar yaitu mother sauces dan small sauces. Mother sauce terdiri dari 5 jenis saus dasar yaitu milk base, white stock, brown stock, tomato base serta butter base. Dari 5 jenis saus dasar itulah kemudian diturunkan menjadi berbagai jenis saus yang dapat dikembangkan sesuai dengan kebutuhan.

Untuk menjadi saus yang baik, saus tersebut harus memiliki kriteria sebagai berikut (Minantyo, 2011):

1. Memiliki rasa khas yang sesuai dengan bahan dasar yang digunakan.

2. Memiliki tingkat kekentalan yang konsisten.

3. Memiliki tekstur yang halus dan tampak mengkilap, serta tidak terdapat gumpalan didalamnya.

4. Tidak terdapat selaput tipis si bagian permukaannya.

\section{Resep White Wine Citrus Sauce Umum}

Resep dan bahan pembuatan white wine citrus sauce disajikan dalam tabel 1 berikut ini: 
Tabel 1. Resep White Wine Citrus Sauce The Ritz-Carlton Pacific Place Jakarta

\begin{tabular}{|l|c|c|l|}
\hline \multicolumn{1}{|c|}{ Ingredient } & Quantity & Unit & \multicolumn{1}{c|}{ Method } \\
\hline White wine & 125 & $\mathrm{ml}$ & $\begin{array}{l}\text { Reduce white wine sampai sedikit } \\
\text { mendidih }\end{array}$ \\
\hline Orange juice & 80 & $\mathrm{ml}$ & $\begin{array}{l}\text { Tambahkan } \text { orange juice, sampai } \\
\text { mendidih }\end{array}$ \\
\hline Dill & 3 & pcs & Masukan dill yang sudah dipotong \\
\hline Lemon & 3 & slice & Lalu tambahkan irisan lemon \\
\hline Butter & 1 & tbs & $\begin{array}{l}\text { Tunggu bahan bahan diatas sampai boil } \\
\text { lalu tambahkan butter }\end{array}$ \\
\hline Salt & $1 / 2$ & tsp & Tambahkan seasoning \\
\hline
\end{tabular}

Sumber : The Ritz-Carlton Pacific Place Jakarta (2020)

\section{Rancangan Percobaan}

Pada penelitian ini, penulis memfokuskan penelitian pada rancangan percobaan untuk mencari bahan pengganti white wine dalam pengolahan citrus sauce, dengan harapan didapatkan rasa saus yang mendekati rasa yang dihasilkan dari bahan baku original, namun tidak menggunakan bahan baku non-halal.

Berikut ini rancangan percobaan tersebut disusun: Percobaan 1 (X1) - Citrus Sauce dengan menggunakan Sprite:

\begin{tabular}{llll} 
No & Ingredient & Quantity & Unit \\
\hline 1 & Sprite & 100 & $\mathrm{ml}$ \\
2 & Orange Juice & 80 & $\mathrm{ml}$ \\
3 & Dill & 3 & $\mathrm{pcs}$ \\
4 & Lemon & 3 & slice \\
5 & Butter & 1 & tbs \\
6 & Salt & $1 / 2$ & tsp
\end{tabular}

Langkah Pembuatan Percobaan 1 :

1. Didihkan Sprite.

2. Tuangkan Orange Juice, lalu didihkan kembali.

3. Masukkan Dill, Salt dan Butter, masak hingga butter meleleh sempurna.

4. Masukkan irisan lemon, masak hingga berkurang $1 / 2$ bagian.

Percobaan 2 (X2) - Citrus Sauce dengan menggunakan Cuka Apel:

\begin{tabular}{llll} 
No & Ingredient & Quantity & Unit \\
\hline 1 & Cuka Apel & 100 & $\mathrm{ml}$ \\
2 & Orange Juice & 80 & $\mathrm{ml}$ \\
3 & Dill & 3 & $\mathrm{pcs}$ \\
4 & Lemon & 3 & slice
\end{tabular}

$\begin{array}{llll}5 & \text { Butter } & 1 & \text { tbs }\end{array}$

6 Salt $1 / 2$ tsp

Langkah Pembuatan Percobaan 2 :

1. Didihkan Cuka Apel.

2. Tuangkan Orange Juice, lalu didihkan kembali.

3. Masukkan Dill, Salt dan Butter, masak hingga butter meleleh sempurna.

4. Masukkan irisan lemon, masak hingga berkurang $1 / 2$ bagian.

Percobaan 3 (X3) - Citrus Sauce dengan menggunakan Chateau de Reignac :

\begin{tabular}{|c|c|c|c|c|}
\hline No & Ingredient & Qua & & Unit \\
\hline$\overline{1}$ & \multicolumn{2}{|c|}{ Chateau de Reignac } & 110 & $\mathrm{ml}$ \\
\hline 2 & Orange Juice & 80 & & $\mathrm{ml}$ \\
\hline 3 & Dill & 3 & & pcs \\
\hline 4 & Lemon & 3 & & slice \\
\hline 5 & Butter & 1 & & tbs \\
\hline 6 & Salt & $1 / 2$ & & $\mathrm{tsp}$ \\
\hline
\end{tabular}

Langkah Pembuatan Percobaan 3:

1. Didihkan Sari Anggur Chateau De Reignac.

2. Tuangkan Orange Juice, lalu didihkan kembali.

3. Masukkan Dill, Salt dan Butter, masak hingga butter meleleh sempurna.

4. Masukkan irisan lemon, masak hingga berkurang $1 / 2$ bagian.

\section{METODOLOGI PENELITIAN}

\section{Metode Penelitian}

Metode yang digunakan dalam penelitian ini adalah metode eksperimen. Menurut (Sugiyono, 2016) metode penelitian eksperimen dapat 
diartikan sebagai metode penelitian yang digunakan untuk mencari pengaruh perlakuan tertentu terhadap yang lain dalam kondisi yang terkendalikan. Sedangkan untuk menguji hasil penelitian ini digunakan Uji Organoleptik, atau pengujian yang didasarkan pada proses penginderaan (Program Studi Teknologi Pangan, 2013).

\section{Teknik Pengumpulan Data}

Teknik penggumpulan data yang penulis gunakan dalam penelitian ini adalah sebagai berikut:

\section{Observasi}

Menurut (Wibowo, 2018) observasi adalah teknik pengumpulan data dengan melakukan pengamatan atau observasi. Dalam kajian ini penulis menggunakan teknik observasi untuk mengamati perubahan tekstur, warna, dan aroma yang terjadi pada olahan saus dengan menggunakan bahan pengganti alternatif seperti Sprite, cuka apel, sari tape dan Chateau De Reignac.

\section{Wawancara}

Menurut (Sugiyono, 2016), wawancara merupakan pertemuan dua orang untuk bertukar informasi dan gagasan melalui tanya jawab, untuk dapat membangun konstruksi makna dalam suatu topik.

Dalam kajian ini, penulis menggunakan teknik wawancara untuk menggali pendapat dari orang orang yang turut mencicipi sauce. Penulis ingin mengetahui apakah ada perbaikan dalam tekstur, warna, aroma dan rasa. Penulis melakukan wawancara kepada 3 juru masak maupun professional dari bidang kuliner.

\section{Penilaian Panel}

Orang yang menjadi anggota panel disebut dengan panelis. Panel inilah yang bertugas menilai sifat atau mutu komoditi berdasarkan kesan subjektif (Program Studi Teknologi Pangan, 2013). Panelis yang digunakan dalam penelitian ini adalah Panelis Terlatih dan Panelis Tidak Terlatih. Data penilaian panel dilakukan dengan menggunakan kuesioner.

\section{Studi Pustaka}

Menurut (Nazir, 2003) Studi pustaka adalah survey terhadap data yang ada, baik berupa hasil penelitian, buku, maupun sumber - sumber pustaka lainnya.

\section{Populasi dan Sampel}

Sampel dalam penelitian ini adalah 3 orang panelis terlatih, yang berprofesi sebagai juru masak maupun yang berkecimpung pada dunia kuliner. Sedangkan untuk sampel panelis tidak terlatih, dipilih 30 orang umum yang merupakan mahasiswa jurusan perhotelan, tata boga, maupun mereka yang memiliki pengetahuan dasar mengenai kuliner,

\section{HASIL DAN PEMBAHASAN}

Hasil penelitian dikategorikan kedalam 2 hasil, yaitu hasil dari panelis terlatih yang didapatkan melalui wawancara mendalam, serta hasil yang didapatkan dari panelis tidak terlatih yang dirangkum melalui kuesioner sederhana.

Berikut ini merupakan rekaman hasil (dokumentasi) dari hasil percobaan yang penulis lakukan dari setiap tahapan percobaan (X1, X2 dan X3) yang disajikan melalui tabel 2.

Tabel 2. Rekaman Hasil Percobaan

\begin{tabular}{|c|l|l|l|}
\hline No & Nama Percobaan & \multicolumn{1}{|c|}{ Hasil } & \multicolumn{1}{|c|}{ Keterangan } \\
\hline 1. & $\begin{array}{l}\text { X1 - Citrus Sauce } \\
\text { Menggunakan Sprite }\end{array}$ & & $\begin{array}{l}\text { Warna yang } \\
\text { dihasilkan kuning } \\
\text { cerah, mengkilap } \\
\text { dengan tekstur } \\
\text { sangat kental. }\end{array}$ \\
\hline
\end{tabular}




\begin{tabular}{|c|l|l|l|}
\hline No & Nama Percobaan & \multicolumn{1}{|c|}{ Hasil } & \multicolumn{1}{c|}{ Keterangan } \\
\hline 2. & $\begin{array}{l}\text { X2 - Citrus Sauce } \\
\text { Menggunakan Cuka } \\
\text { Apel } \\
\text { dihasilkan kuning } \\
\text { gelap, dengan } \\
\text { tekstur lebih kental. }\end{array}$ & $\begin{array}{l}\text { Warna yang } \\
\text { dihasilkan kuning, } \\
\text { dengan tekstur } \\
\text { cukup kental. }\end{array}$ \\
\hline 3. & $\begin{array}{l}\text { X3 - Citrus Sauce } \\
\text { Menggunakan } \\
\text { Chateau deReignac }\end{array}$ & & \\
\hline
\end{tabular}

Pada Citrus Sauce yang menggunakan Sprite, didapati saus cenderung lebih manis, dengan warna yang lebih terang dibanding menggunakan white wine. Aroma yang dihasilkan juga lebih manis dan memiliki tekstur yang lebih kental dibanding dengan Citrus Sauce original.

Citrus Sauce yang menggunakan cuka apel, rasa cenderung asam, dengan aroma asam khas cuka yang sangat menyengat. Tekstur yang dihasilkan hampir mendekati yang asli sedangkan warna jauh lebih gelap dibandingkan dengan saus original.

Pada Citrus Sauce yang menggunakan Chateau de Reignac rasa yang dihasilkan manis yang seimbang, dengan aroma yang dihasilkan adalah aroma khas anggur yang mirip dengan yang asli. Warna yang dihasilkan lebih terang dibanding yang asli dengan tekstur juga mendekati yang asli dan tidak terlalu kental.

Hasil penelitian diatas, selanjutnya diuji panel terhadap panelis terlatih dan panelis tidak terlatih sesuai dengan percobaan yang telah penulis rancang sebelumnya. Dalam pengujian panelis, digunakan kriteria penilaian untuk mendapatkan hasil yang baik.

Standar kriteria penilaian bagi panelis dijelaskan pada tabel 3 dan tabel 4 sebagai berikut:

Tabel 3. Kriteria Penilaian Panelis

\begin{tabular}{|l|c|}
\hline \multicolumn{1}{|c|}{ Kriteria Penilaian } & Nilai \\
\hline Sangat Enak/ Sangat Menarik/ Sangat Sedap & 5 \\
\hline Enak/ Menarik/ Sedap & 4 \\
\hline Cukup Enak/ Cukup Menarik/ Cukup Sedap & 3 \\
\hline Kurang Enak/ Kurang Menarik/ Kurang Sedap & 2 \\
\hline Tidak Enak/ Tidak Menarik/ Tidak Sedap/ Tidak Bagus & 1 \\
\hline
\end{tabular}

Tabel 4. Interval Penilaian Panelis

\begin{tabular}{|c|l|}
\hline Interval & \multicolumn{1}{c|}{ Kategori } \\
\hline $4,20-5.00$ & Sangat Enak/ Sangat Menarik/ Sangat Sedap \\
\hline $3,40-4,19$ & Enak/ Menarik/ Sedap \\
\hline $2,60-3,39$ & Cukup Enak/ Cukup Menarik/ Cukup Sedap \\
\hline $1,80-2,59$ & Kurang Enak/ Kurang Menarik/ Kurang Sedap \\
\hline $1,00-1,79$ & Tidak Enak/ Tidak Menarik/ Tidak Sedap/ Tidak Bagus \\
\hline
\end{tabular}


Untuk menghitung rata - rata jawaban berdasarkan nilai dari para panelis dan berdasarkan nilai yang telah ditetapkan. Berikut adalah rumus menghitung rata - rata :

$$
\bar{x}=\frac{\sum f(x)}{n}
$$

Keterangan

$\mathrm{X}^{-}$ $\sum f(x) \quad$ : Hasil penjumlahan dari jumlah frekuensi dikali dengan skor penilaian panelis. $\mathrm{n} \quad$ : Jumlah panelis.

Hasil perhitungan uji panelis secara lengkap disajikan pada tabel 5 sebagai berikut:

Tabel 5: Skor Penilaian Panelis Tidak Terlatih Pada Citrus Sauce (X1) (n30)

\begin{tabular}{|c|c|c|c|c|c|c|c|c|c|c|c|c|c|}
\hline \multicolumn{10}{|c|}{ Skor Penilaian Panelis Tidak Terlatih Pada Citrus Sauce (X1) (n30) } \\
\hline \multirow{2}{*}{ No } & $\begin{array}{c}\text { Aspek } \\
\text { Penilaian }\end{array}$ & \multicolumn{2}{|c|}{1} & \multicolumn{2}{|c|}{2} & \multicolumn{2}{|c|}{3} & \multicolumn{2}{|c|}{4} & \multicolumn{2}{|c|}{5} & Total & - \\
\hline 1 & Rasa & & & & & 4 & 12 & 16 & 64 & 10 & 50 & 126 & 4.33 \\
\hline 2 & Warna & & & & & 10 & 30 & 18 & 72 & 2 & 10 & 112 & 3.73 \\
\hline 3 & Aroma & & & 2 & 4 & 10 & 30 & 12 & 48 & 6 & 30 & 112 & 3.73 \\
\hline 4 & Tekstur & & & & & 20 & 60 & 8 & 32 & 2 & 10 & 102 & 3.40 \\
\hline
\end{tabular}

Dari data pada Tabel 5, skor penilaian panelis tidak terlatih untuk citrus sauce $\mathrm{X} 1$ yang dilakukan pada 30 panelis, dapat diketahui nilai pada masing - masing aspek yaitu rasa, warna, aroma dan tekstur sebagai berikut :

a. Hasil Penilaian Aspek Rasa

Nilai citrus sauce X1 pada aspek rasa dari penjumlahan hasil panelis tidak terlatih mendapatkan 126 poin dengan nilai rata - rata rasa 4.33. Demikian untuk penilaian rasa pada citrus sauce $\mathrm{X} 1$ yaitu cukup sangat enak.

b. Hasil Penilaian Aspek Warna

Nilai citrus sauce X1 pada aspek warna dari penjumlahan hasil panelis tidak terlatih mendapatkan 112 poin dengan nilai rata - rata warna 3.73. Demikian untuk penilaian warna pada citrus sauce $\mathrm{X} 1$ yaitu menarik.

c. Hasil Penilaian Aspek Aroma

Nilai citrus sauce X1 pada aroma rasa dari penjumlahan hasil panelis tidak terlatih mendapatkan 112 poin dengan nilai rata - rata aroma 3.73. Demikian untuk penilaian warna pada citrus sauce X1 yaitu sedap.

d. Hasil Penilaian Aspek Tekstur

Nilai citrus sauce X1 pada aspek tekstur dari penjumlahan hasil panelis tidak terlatih mendapatkan 102 poin dengan nilai rata - rata tekstur 3.40. Demikian untuk penilaian tekstur pada citrus sauce $\mathrm{X} 1$ yaitu menarik.

Tabel 6: Skor Penilaian Panelis Tidak Terlatih Pada Citrus Sauce (X2) (n30)

\begin{tabular}{|c|c|c|c|c|c|c|c|c|c|c|c|c|c|}
\hline \multicolumn{14}{|c|}{ Skor Penilaian Panelis Tidak Terlatih Pada Citrus Sauce (X2) (n30) } \\
\hline \multirow{2}{*}{ No } & \multirow{2}{*}{$\begin{array}{c}\text { Aspek } \\
\text { Penilaian }\end{array}$} & \multicolumn{2}{|c|}{1} & \multicolumn{2}{|c|}{2} & \multicolumn{2}{|c|}{3} & \multicolumn{2}{|c|}{4} & \multicolumn{2}{|c|}{5} & \multirow{2}{*}{$\begin{array}{c}\text { Total } \\
\mathrm{f}(\mathrm{x})\end{array}$} & \multirow[t]{2}{*}{-} \\
\hline & & $\mathrm{F}$ & $f(x)$ & $\mathrm{F}$ & $f(x)$ & $\mathrm{F}$ & $f(x)$ & $\mathrm{F}$ & $f(x)$ & $\mathrm{F}$ & $f(x)$ & & \\
\hline 1 & Rasa & 8 & 8 & 14 & 28 & 8 & 24 & & & & & 60 & 2.00 \\
\hline
\end{tabular}




\begin{tabular}{|l|l|l|l|c|c|c|c|c|c|c|c|c|c|}
\hline 2 & Warna & & & 16 & 32 & 12 & 36 & 2 & 8 & & & 76 & 2.53 \\
\hline 3 & Aroma & 18 & 18 & 12 & 24 & & & & & & & 42 & 1.40 \\
\hline 4 & Tekstur & & & 2 & 8 & 14 & 42 & 12 & 48 & 2 & 10 & 98 & 3.26 \\
\hline
\end{tabular}

Dari data pada Tabel 6 diatas, skor penilaian panelis tidak terlatih untuk citrus sauce $\mathrm{X} 2$ yang dilakukan pada 30 panelis, dapat diketahui nilai pada masing - masing aspek yaitu rasa, warna, aroma dan tekstur sebagai berikut :

a. Hasil Penilaian Aspek Rasa

Nilai citrus sauce X2 pada aspek rasa dari penjumlahan hasil panelis tidak terlatih mendapatkan 60 poin dengan nilai rata - rata rasa 2.00. Demikian untuk penilaian rasa pada citrus sauce $\mathrm{X} 2$ yaitu kurang enak.

b. Hasil Penilaian Aspek Warna

Nilai citrus sauce X2 pada aspek warna dari penjumlahan hasil panelis tidak terlatih mendapatkan 76 poin dengan nilai rata - rata warna 2.53. Demikian untuk penilaian warna pada citrus sauce $\mathrm{X} 2$ yaitu kurang menarik.

c. Hasil Penilaian Aspek Aroma

Nilai citrus sauce X2 pada aspek aroma dari penjumlahan hasil panelis tidak terlatih mendapatkan 42 poin dengan nilai rata - rata aroma 1,40. Demikian untuk penilaian aroma pada citrus sauce X2 yaitu tidak sedap.

d. Hasil Penilaian Aspek Tekstur
Nilai citrus sauce X2 pada aspek tekstur dari penjumlahan hasil panelis tidak terlatih mendapatkan 98 poin dengan nilai rata - rata tekstur 3.26. Demikian untuk penilaian tekstur pada citrus sauce X2 yaitu cukup menarik.

Pada Tabel 7, skor penilaian panelis tidak terlatih untuk citrus sauce X3 yang dilakukan pada 30 panelis, dapat diketahui nilai pada masing masing aspek yaitu rasa, warna, aroma dan tekstur sebagai berikut :

a. Hasil Penilaian Aspek Rasa

Nilai citrus sauce X3 pada aspek rasa dari penjumlahan hasil panelis tidak terlatih mendapatkan 106 poin dengan nilai rata - rata tekstur 3.53. Demikian untuk penilaian tekstur pada citrus sauce X3 yaitu enak.

b. Hasil Penilaian Aspek Warna

Nilai citrus sauce X3 pada aspek warna dari penjumlahan hasil panelis tidak terlatih mendapatkan 96 poin dengan nilai rata - rata tekstur 3.20. Demikian untuk penilaian warna pada citrus sauce X3 yaitu cukup menarik.

Tabel 7: Skor Penilaian Panelis Tidak Terlatih Pada Citrus Sauce (X3) (n30)

\begin{tabular}{|c|c|c|c|c|c|c|c|c|c|c|c|c|c|}
\hline \multicolumn{10}{|c|}{ Skor Penilaian Panelis Tidak Terlatih Pada Citrus Sauce (X3) (n30) } \\
\hline \multirow{2}{*}{ No } & $\begin{array}{c}\text { Aspek } \\
\text { Penilaian }\end{array}$ & \multicolumn{2}{|c|}{1} & \multicolumn{2}{|c|}{2} & \multicolumn{2}{|c|}{3} & \multicolumn{2}{|c|}{4} & \multicolumn{2}{|c|}{5} & Total & - \\
\hline & & F & $\mathrm{f}(\mathrm{x})$ & $\mathrm{F}$ & $\mathrm{f}(\mathrm{x})$ & $\mathrm{F}$ & $\mathrm{f}(\mathrm{x})$ & $\mathrm{F}$ & $\mathrm{f}(\mathrm{x})$ & $\mathrm{F}$ & $\mathrm{f}(\mathrm{x})$ & $\mathrm{f}(\mathrm{x})$ & \\
\hline 1 & Rasa & & & 2 & 4 & 12 & 36 & 14 & 56 & 2 & 10 & 106 & 3.53 \\
\hline 2 & Warna & 2 & 2 & 2 & 4 & 14 & 42 & 12 & 48 & & & 96 & 3.2 \\
\hline 3 & Aroma & & & 4 & 8 & 8 & 24 & 16 & 64 & 2 & 10 & 106 & 3.53 \\
\hline 4 & Tekstur & & & 6 & 12 & 14 & 42 & 10 & 40 & & & 94 & 3.13 \\
\hline
\end{tabular}

c. Hasil Penilaian Aspek Aroma

Nilai citrus sauce X3 pada aspek aroma dari penjumlahan hasil panelis tidak terlatih mendapatkan 106 poin dengan nilai rata - rata tekstur 3.53. Demikian untuk penilaian tekstur pada citrus sauce X2 yaitu sedap. d. Hasil Penilaian Aspek Tekstur

Nilai citrus sauce X3 pada aspek tekstur dari penjumlahan hasil panelis tidak terlatih mendapatkan 94 poin dengan nilai rata - rata tekstur 3.13. Demikian untuk penilaian tekstur pada citrus sauce X2 yaitu cukup menarik. 
Tabel 8: Skor Hasil Perbandingan Penilaian Panelis (X1), (X2) dan (X3)

\begin{tabular}{|c|c|c|c|c|}
\hline \multirow{2}{*}{ No } & \multirow{2}{*}{$\begin{array}{c}\text { Aspek } \\
\text { Penilaian }\end{array}$} & \multicolumn{3}{|c|}{ Rata - Rata Hasil Penilaian } \\
\cline { 3 - 5 } & & $\mathbf{X 1}$ - Sprite & $\mathbf{X 2}-$ Cuka Apel & $\begin{array}{c}\text { X3 - Chateau } \\
\text { deReignac }\end{array}$ \\
\hline 1 & Rasa & 4.33 & 2.00 & 3.53 \\
\hline 2 & Warna & 3.73 & 2.53 & 3.20 \\
\hline 3 & Aroma & 3.73 & 1.40 & 3.53 \\
\hline 4 & Tekstur & 3.40 & 3.26 & 3.13 \\
\hline
\end{tabular}

Berdasarkan perbandingan hasil penilaian panelis pada tabel 8 , didapatkan kesimpulan bahwa saus dengan bahan baku pengganti Sprite (X1) sebagai hasil yang terbaik, baik dari segi rasa, warna, aroma dan tekstur.

Setelah data disatukan dengan hasil wawancara terhadap panelis terlatih, didapatkan data bahwa walaupun dari berbagai aspek Citrus Sauce dengan Sprite (X1) mendapatkan penilaian terbaik, namun dari aspek rasa maupun warna masih belum sempurna dan belum mendekati saus original. Dari segi rasa, hasil citrus sauce dengan Sprite (X1) menonjolkan rasa yang dominan manis, berbeda dengan saus aslinya yang menonjolkan rasa manis dan asam khas orange. Terhadap aspek aroma, citrus sauce dengan Sprite juga memiliki kelemahan yaitu aroma yang cenderung datar dan tidak dapat menonjolkan aroma masam khas wine yang ditemui pada saus asli.

Berdasarkan hasil tersebut, penilaian panelis profesional menyarankan untuk melakukan penelitian lanjutan dalam pembuatan citrus sauce dengan mengkombinasikan Sprite dan Cuka Apel (X4). Penulis melaksanakan saran yang diberikan oleh Panelis Terlatih dan menghasilkan rasa, warna, tekstur dan aroma yang lebih baik dan mendekati dibandingkan dengan citrus sauce (X1), (X2), dan (X3). Berikut ini resep untuk citrus sauce yang menggunakan sprite dan cuka apel (X4) tersaji pada tabel 12, sebagai berikut :

\begin{tabular}{llll} 
No & Ingredient & Quantity & Unit \\
\hline 1 & Sprite & 70 & $\mathrm{ml}$ \\
2 & Cuka Apel & 50 & $\mathrm{ml}$ \\
3 & Orange Juice & 80 & $\mathrm{ml}$ \\
4 & Dill & 3 & $\mathrm{pcs}$ \\
5 & Lemon & $1 / 2$ & slice \\
6 & Butter & $1 / 2$ & $\mathrm{tbs}$ \\
7 & Salt & $1 / 4$ & $\mathrm{tsp}$
\end{tabular}

Langkah Pembuatan :

1. Didihkan Sprite dan Cuka Apel.

2. Tuangkan Orange Juice, lalu didihkan kembali.

3. Masukkan Dill, Salt dan Butter, masak hingga butter meleleh sempurna.

4. Masukkan irisan lemon, masak hingga berkurang $1 / 2$ bagian.

Berikut adalah rekaman hasil citrus sauce yang menggunakan bahan sprite dan cuka apel yang tersaji pada tabel 9 berikut ini:

Tabel 9: Rekaman Hasil Percobaan Lanjutan (X4)

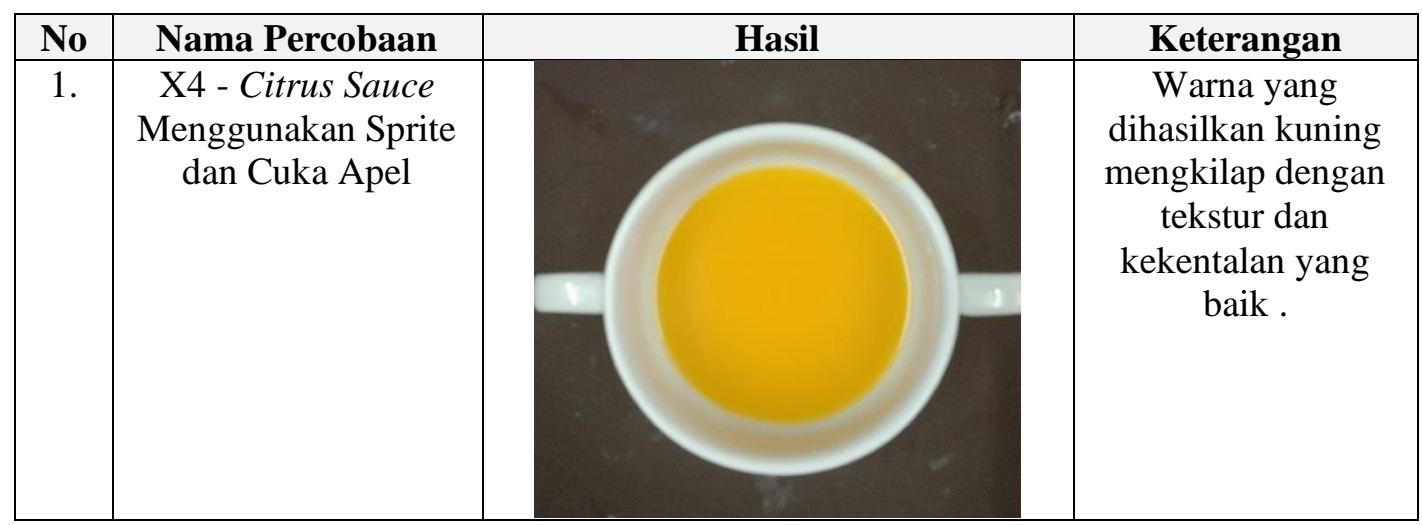


Hasil citrus sauce yang menggunakan sprite dan cuka apel, dapat menimbulkan rasa yang berimbang antara manis dan rasa masam, seperti layaknya wine. Aromanya juga memiliki aroma yang masam seperti aroma anggur, dengan tekstur dan warna mendekati yang asli dan lebih menarik dan terang. Secara keseluruhan hasil percobaan citrus sauce dengan Sprite dan Cuka Apel dapat memunculkan hasil yang paling mendekati saus original.

\section{SIMPULAN DAN REKOMENDASI}

Penggantian white wine dalam pembuatan citrus sauce, menghasilkan aroma yang unik dari penggunaan bahan alternatif, serta dapat memunculkan warna yang khas tergantung dari bahan alternatif yang digunakan. Hal ini menciptakan perpaduan rasa yang unik dan khas, menghasilkan tekstur yang lebih cair. Namun secara keseluruhan, kesimpulan yang didapat adalah penggunaan white wine pada saus, pada dasarnya dapat diganti dengan bahan alternatif yaitu Sprite dan Cuka Apel.

Penulis juga menemukan kesulitan dan hambatan dalam melakukan eksperimen penggantian white wine dalam pembuatan citrus sauce, yakni dalam melakukan penyusutan cuka apel yang terlalu berlebih dapat menyebabkan aroma asam dari cuka apelnya menghilang dan akan menimbulkan bau asam yang tidak enak, jika tidak dilakukan proses penyusutan kepada cuka apel dapat menyebabkan aroma asam yang sangat kuat dan tidak sedap, jadi penulis harus terus memperhatikan diproses penyusutan cuka apel tersebut.

\section{REFERENSI}

Cahyana, C., \& Devi, G. (2015). Buku Pintar Masak Hidangan Kontinental (1st ed.; I. Hardiman, ed.). Jakarta: PT Gramedia Pustaka Utama.

Gisslen, W. (2011). Professional Cooking, Seventh Edition (7th ed.). New Jersey: John Wiley \& Sons, Inc.

Labensky, S. R., Hause, A. M., \& Martel, P. A. (2015). On Cooking a Textbook of Culinary Fundamentals (5th ed.; V. R. Anthony \& W. R. Lawrensen, eds.). New Jersey: Pearson Education.

Minantyo, H. (2011). Dasar-dasar Pengolahan Makanan (Food Product Fundamenta). Yogyakarta: Graha Ilmu.
Nazir, M. (2003). Metode Penelitian (5th ed.; R. Agustine \& R. F. Sikumbank, eds.). Jakarta: Penerbit Ghalia Indonesia.

Program Studi Teknologi Pangan. (2013). Pengujian Organoleptik. Semarang.

Sugiyono. (2016). Memahami Penelitian Kualitatif. Bandung: Alfabeta.

Wahyudin, U., Fathurrahman, \& Fuziani, F. (2008). Fikih untuk Kelas V Madrasah Ibtidaiyah (1st ed.; Mahmud, A. Dimyati, \& M. Indrianti, eds.). Bandung: Grafindo Media.

Wibowo. (2018). Manajemen Kinerja, Edisi Kelima (5th ed.). Jakarta: PT Rajagrafindo Persada.

\section{BIODATA PENULIS}

Swastono Putro Pirastyo, M.Par., merupakan dosen Akademi Pariwisata Nasional Indonesia Bandung, memiliki latar belakang keilmuan Pariwisata, dan mendalami bidang kajian Pariwisata dan Pengolahan Makanan.

Roby Sahid, A.Md. Par., merupakan wirausaha muda, yang memiliki bidang keahlian pada pengolahan dan kreasi makanan. 